\title{
Chemical Stability of Chromium Carbide and Chromium Nitride Powders Compared with Chromium Metal in Synthetic Biological Solutions
}

\author{
Tao Jiang, Inger Odnevall Wallinder, and Gunilla Herting \\ Division of Surface and Corrosion Science, School of Chemical Science and Engineering, KTH Royal Institute of Technology, \\ Drottning Kristinas väg 51, 10044 Stockholm, Sweden \\ Correspondence should be addressed to Gunilla Herting, herting@kth.se
}

Received 7 March 2012; Accepted 6 May 2012

Academic Editors: K. N. Allahar, L. Bazzi, and R. Wang

Copyright ( $\odot 2012$ Tao Jiang et al. This is an open access article distributed under the Creative Commons Attribution License, which permits unrestricted use, distribution, and reproduction in any medium, provided the original work is properly cited.

Chromium carbide (Cr-C) and chromium nitride (Cr-N) powders were compared with a chromium metal powder (Cr-metal) to evaluate their chemical stability in solution. All three powders were exposed in five different synthetic biological solutions of varying $\mathrm{pH}$ and chemical composition simulating selected human exposure conditions. Characterisation of the powders, using GI-XRD, revealed that the predominant bulk crystalline phases were $\mathrm{Cr} 7 \mathrm{C} 3$ and $\mathrm{Cr} 2 \mathrm{~N}$ for $\mathrm{Cr}-\mathrm{C}$ and $\mathrm{Cr}-\mathrm{N}$ respectively. The outermost surface of $\mathrm{Cr}-\mathrm{C}$, determined by XPS, contained $\mathrm{Cr} 7 \mathrm{C} 3$ and $\mathrm{Cr} 2 \mathrm{O} 3$ and the corresponding measurement on $\mathrm{Cr}-\mathrm{N}$ revealed $\mathrm{Cr} 2 \mathrm{~N}$ and $\mathrm{CrN}$ apart from $\mathrm{Cr} 2 \mathrm{O} 3$. The presence of $\mathrm{Cr} 2 \mathrm{O} 3$ was verified by XPS investigations of the Cr-metal powder. The mean particle size was similar for Cr-metal and Cr-N but slightly smaller for Cr-C. All three powders were poorly soluble and released very low amounts of chromium $(<0.00015 \mu \mathrm{g} \mathrm{Cr} / \mu \mathrm{g}$ loaded particles $)$ independent on test solution. Slightly higher chromium concentrations were determined in the more acidic media ( $\mathrm{pH} 1.7$ and 4.5) compared with the near-neutral solutions ( $\mathrm{pH} 7.2$ and 7.4). Cr-C released the lowest amount of $\mathrm{Cr}$ despite having the largest surface area a feature attributed to the strong covalent bonds within the matrix.

\section{Introduction}

Chromium metal and chromium compounds are used in a wide variety of applications ranging from alloying to tanning of animal hides to pigmentation. The extensive use raises questions concerning the potential adverse effect on human health and on the environment. Within the European Community regulatory frame work, REACH, (Registration, Evaluation, Authorization and Restriction of Chemicals), the responsibility to ensure that all products are safe for use lies on the industry and they are consequently required to provide information on the product properties to allow safe handling.

Elaborate studies have been performed generating data on release, dissolution, and solubility aspects of chromium and chromium-containing alloys such as stainless steels and ferrochromium alloys [1-9], data that has been utilised within the framework of the European chemicals legislation (REACH) implemented in 2007. Bioaccessibility and environmental impact aspects of chromium have been discussed by, for example, [9-11]. Dissolution studies concerning chromium-containing materials like chromium carbide and chromium nitride are, however, much scarcer and have not been performed with the purpose to evaluate interactions with the environment or the human body $[12,13]$. Both chromium carbide and chromium nitride are commonly used as coatings on stainless steels, enhancing the wear and corrosion resistance, and have accordingly been thoroughly investigated [14-20]. Chromium carbide $\left(\mathrm{Cr}_{3} \mathrm{C}_{2}\right)$ has been shown to be practically insoluble in boiling $\mathrm{HCl}$ [12] whereas $\mathrm{Cr}_{2} \mathrm{~N}$ was shown to have higher solubility in $\mathrm{HCl}$ compared with $\mathrm{CrN}$ [13]. In addition, surface and bulk characteristics of both chromium carbide and chromium nitride have been carefully examined with techniques such as XPS, SEM, and XRD [21-25].

Exposing metal and ceramic powders in synthetic body fluids is important in order to understand and gain information on how the particles and potential metal release from 
TABLE 1: Bulk composition (wt $\%$ ) of different chromium-based test items.

\begin{tabular}{lccccccc}
\hline $\begin{array}{l}\text { Test } \\
\text { item }\end{array}$ & $\mathrm{Cr}$ & $\mathrm{Fe}$ & $\mathrm{C}$ & $\mathrm{N}$ & $\mathrm{Si}$ & $\mathrm{Al}$ & $\mathrm{O}$ \\
\hline $\mathrm{Cr}$ & $>99.75$ & 0.07 & 0.012 & - & 0.025 & - & 0.045 \\
$\mathrm{Cr}-\mathrm{C}$ & balance & 0.077 & 10.1 & 0.007 & 0.021 & 0.015 & 0.075 \\
$\mathrm{Cr}-\mathrm{N}$ & balance & 0.04 & 0.006 & 8.2 & 0.013 & $<0.003$ & 0.15 \\
\hline
\end{tabular}

the powders may influence the environment or the human body.

Occupational exposure to airborne powders of chromium carbide and chromium nitride is a potential issue during manufacture and use and information on released chromium is, therefore, essential to assess potential risks on human health and the environment.

In this study, powders of chromium metal, chromium carbide $\left(\mathrm{Cr}_{7} \mathrm{C}_{3}\right)$, and chromium nitride $\left(\mathrm{Cr}_{2} \mathrm{~N}\right)$ were exposed to five different synthetic body fluids to investigate the extent of chromium release. The total released amount of chromium was measured with graphite furnace atomic absorption spectroscopy, GF-AAS, the surface composition was evaluated by means of X-ray photoelectron spectroscopy, XPS, and the bulk composition and phase composition were determined using grazing incidence X-ray diffraction, GIXRD.

The objective was to provide a unique set of in vitro bioaccessibility data for use within the framework of REACH.

\section{Experimental}

Powders of Cr-metal (sized less than $25 \mu \mathrm{m}$ ), chromium carbide ( $\mathrm{Cr}-\mathrm{C}$, sized less than $40 \mu \mathrm{m}$ ), and chromium nitride (Cr-N, sized less than $40 \mu \mathrm{m}$ ) were supplied by Delachaux, France. The Cr-metal powder was crushed, sieved, and recrushed to produce similar particle sizes as the $\mathrm{Cr}-\mathrm{C}$ and the $\mathrm{Cr}-\mathrm{N}$ powders. Chemical bulk compositions based on supplier information are presented in Table 1.

Measurement of the specific surface area per weight, $\mathrm{m}^{2} / \mathrm{g}$, was performed using BET analysis (nitrogen absorption at cryogenic conditions) using a Micromeritics Gemini $\mathrm{V}$ instrument at five different local areas.

Particle size distribution measurements were conducted for at least two different samples of each powder in phosphate buffered saline (PBS) using a Malvern Mastersizer 2000 instrument with a Hydro SM dispersion unit operating at standard conditions. Refractive indexes for chromium (3.51) and water (1.33), water is the solvent for PBS, were used as input parameters.

Particle morphology of the powders was examined by means of scanning electron microscopy, using a field emission gun scanning electron microscope, FEG-SEM, LEO 1530 instrument with a Gemini column.

Identification of possible crystalline phases was accomplished by grazing incidence X-ray diffraction, GI-XRD, carried out with an X'pert PRO PANALYTICAL system, equipped with an $\mathrm{X}$-ray mirror $(\mathrm{CuK} \alpha$ radiation- $\lambda=$
$1.54050 \AA, 35 \mathrm{~mA}, 45 \mathrm{kV}$ ) and a $0.27^{\circ}$ parallel plate collimator on the diffracted side. The measurements were performed with a grazing angle of $88^{\circ}$ versus the surface normal.

X-ray photoelectron spectroscopy, XPS, UltraDLD spectrometer, Kratos Analytical, Manchester, UK, with a monochromatic Al X-ray source (150 W) was utilised to determine the composition of the outermost surface film $(2-10 \mathrm{~nm})$. Wide- and high-resolution spectra (20 eV pass energy) of Cr2p, N1s, O1s, and C1s were at three different areas. Calibration was conducted performed assigning the $\mathrm{C}-\mathrm{C}, \mathrm{C}-\mathrm{H}$ peak to $285.0 \mathrm{eV}$. A linear base line was employed for all spectra.

All laboratory equipment was acid cleaned for a minimum of 24 hours in 10\% nitric acid and rinsed four times with ultrapure water (MilliQ $18.2 \mathrm{M} \Omega \mathrm{cm}$ ) and dried in ambient air prior to use. All fluids were prepared using ultrapure water $(18.2 \mathrm{M} \Omega \mathrm{cm})$ and analytical grade chemicals. The compositions of the individual fluids are presented in Tables 2 and 3.

Exposures were conducted for periods of 2, 4, 8, 24, and 168 hours using triplicate samples and a powder loading of $5 \pm 0.05 \mathrm{mg}$ in $50 \mathrm{~mL}$ test solution for each exposure period. Powders were weighed using Nalge polymethylpentene (PMP) vessels on a Mettler AT20 balance (readability $2 \mu \mathrm{g}$ ) to which $50 \mathrm{~mL}$ test solution was carefully added. Blank samples ( $50 \mathrm{~mL}$ of test solution without addition of powders) were exposed in parallel for all exposure periods. The vessels were placed in a Stuart platform rocker incubator, shaking at bilinear conditions ( 25 cycles per minute) at $37 \pm 0.5^{\circ} \mathrm{C}$.

After completed exposures, remaining particles were removed from the solution by centrifugation, $3000 \mathrm{rpm}$ for 10 minutes, and the supernatant was decanted into an HDPE flask. The supernatant was acidified with $65 \%$ supra pure nitric acid to a $\mathrm{pH}$ less than 2 prior to total metal concentration analysis, a standard analytical procedure to ensure that all metal is in solution. Successful removal of all particles from the supernatant was confirmed by dynamic light scattering (Malvern Zetasizer nano-ZS instrument).

Total chromium concentrations were determined using graphite furnace atomic absorption spectroscopy, GF-AAS, using a PerkinElmer AAnalyst 800 instrument. Measured concentrations were based on triplicate readings of each sample and quality control samples were analysed every eight samples. The limit of detection (LOD) for chromium in each test fluid is given in Table 3.

\section{Results and Discussion}

3.1. Bulk and Surface Characteristics of Nonexposed Powders. Differences in particle shape and morphology between the investigated powders are displayed in Figure 1. Individual particles of the crushed (cf. experimental) Cr-metal powder were predominantly shaped as thin $(1-5 \mu \mathrm{m}$ ) flakes, typically sized between 10 and $20 \mu \mathrm{m}$, Figures 1 (a) and 1(b). The particles were highly irregular and revealed cracks as a consequence of the brittle properties of chromium metal and the crushing procedure. The BET-area was determined to $0.46 \mathrm{~m}^{2} / \mathrm{g}$. The surface area of the $\mathrm{Cr}-\mathrm{N}$ powder was relatively similar, $0.61 \mathrm{~m}^{2} / \mathrm{g}$, and the particles displayed the presence of 
TABLE 2: Chemical composition (g/L) of artificial biological fluids (GST—gastric fluid [26, 27]; ALF—artificial lysosomal fluid [28]; ASW— artificial sweat [29]; GMB—Gamble's solution [30]; PBS—phosphate buffered saline [31]).

\begin{tabular}{|c|c|c|c|c|c|}
\hline Chemical & $\begin{array}{c}\text { GST } \\
\mathrm{g} / \mathrm{L}\end{array}$ & $\begin{array}{c}\text { ALF } \\
\mathrm{g} / \mathrm{L}\end{array}$ & $\begin{array}{c}\text { ASW } \\
\text { g/L }\end{array}$ & $\begin{array}{c}\text { GMB } \\
\mathrm{g} / \mathrm{L}\end{array}$ & $\begin{array}{c}\text { PBS } \\
g / L\end{array}$ \\
\hline $\mathrm{MgCl}_{2}$ & - & 0.050 & - & 0.095 & - \\
\hline $\mathrm{NaCl}$ & - & 3.21 & 5.00 & 6.02 & 8.77 \\
\hline $\mathrm{KCl}$ & - & - & - & 0.298 & - \\
\hline $\mathrm{Na}_{2} \mathrm{HPO}_{4}$ & - & 0.071 & - & 0.126 & 1.28 \\
\hline $\mathrm{Na}_{2} \mathrm{SO}_{4}$ & - & 0.039 & - & 0.063 & - \\
\hline $\mathrm{CaCl}_{2} \cdot 2 \mathrm{H}_{2} \mathrm{O}$ & - & 0.128 & - & 0.368 & - \\
\hline $\mathrm{C}_{2} \mathrm{H}_{3} \mathrm{O}_{2} \mathrm{Na} \cdot \mathrm{H}_{2} \mathrm{O}$ (sodium acetate) & - & - & - & 0.700 & - \\
\hline $\mathrm{NaHCO}_{3}$ & - & - & - & 2.60 & - \\
\hline $\mathrm{C}_{6} \mathrm{H}_{5} \mathrm{Na}_{3} \mathrm{O}_{7} \cdot 2 \mathrm{H}_{2} \mathrm{O}$ (sodium citrate) & - & 0.077 & - & 0.097 & - \\
\hline $\mathrm{NaOH}$ & - & 6.00 & - & - & - \\
\hline Citric acid & - & 20.8 & - & - & - \\
\hline Glycine & - & 0.059 & - & - & - \\
\hline $\mathrm{C}_{4} \mathrm{H}_{4} \mathrm{O}_{6} \mathrm{Na}_{2} \cdot 2 \mathrm{H}_{2} \mathrm{O}\left(\mathrm{Na}_{2}\right.$ Tartrate $\left.\cdot 2 \mathrm{H}_{2} \mathrm{O}\right)$ & - & 0.090 & - & - & - \\
\hline $\mathrm{C}_{3} \mathrm{H}_{5} \mathrm{NaO}_{3}(\mathrm{Na}$ Lactate $)$ & - & 0.085 & - & - & - \\
\hline $\mathrm{C}_{3} \mathrm{H}_{5} \mathrm{O}_{3} \mathrm{Na}$ (Na Pyruvate) & - & 0.086 & - & - & - \\
\hline $\mathrm{KH}_{2} \mathrm{PO}_{4}$ & - & - & - & - & 1.36 \\
\hline Urea & - & - & 1.00 & - & - \\
\hline Lactic acid & - & - & 1.00 & - & - \\
\hline $\mathrm{HCl}$ & 10 & - & - & - & - \\
\hline $\mathrm{pH}$ & 1.7 & 4.5 & 6.5 & 7.4 & 7.2 \\
\hline
\end{tabular}

TABLE 3: Limits of detection (LOD) of chromium in different biological solutions using GF-AAS, graphite furnace atomic absorption spectroscopy $(\mu \mathrm{g} / \mathrm{L})$.

\begin{tabular}{lcccc}
\hline $\begin{array}{l}\mathrm{GMB} \\
\mu \mathrm{g} / \mathrm{L}\end{array}$ & $\begin{array}{c}\text { PBS } \\
\mu \mathrm{g} / \mathrm{L}\end{array}$ & $\begin{array}{c}\text { ASW } \\
\mu \mathrm{g} / \mathrm{L}\end{array}$ & $\begin{array}{c}\text { ALF } \\
\mu \mathrm{g} / \mathrm{L}\end{array}$ & $\begin{array}{c}\mathrm{GST} \\
\mu \mathrm{g} / \mathrm{L}\end{array}$ \\
\hline 0.7 & 0.2 & 0.3 & 0.3 & 0.5 \\
\hline
\end{tabular}

several large chiselled boulder-like particles, typically sized $20-30 \mu \mathrm{m}$, to which smaller-sized particles ( $\leqslant 5 \mu \mathrm{m})$ adhered to a large extent, Figures $1(\mathrm{c})$ and $1(\mathrm{~d})$. In addition, a significant amount of smaller-sized particles $(<10 \mu \mathrm{m})$, all with sharp edges, were present within the powder. Despite large differences in particle sizes and morphology between the $\mathrm{Cr}$ metal and the $\mathrm{Cr}-\mathrm{N}$ powder, very similar surface areas were established, an effect believed to be related to the highly cracked surface of individual Cr metal flakes increasing the surface area. The $\mathrm{Cr}-\mathrm{C}$ powder revealed similar particle morphology as the Cr-N powder except for the presence of significantly larger numbers of smaller-sized particles $(<10 \mu \mathrm{m})$ and the presence of only few, though very large boulders, Figures 1(e) and 1(f). As a consequence, this powder resulted in the largest measured surface area, $1.26 \mathrm{~m}^{2} / \mathrm{g}$.

$\mathrm{Cr}_{2} \mathrm{~N}$ was identified as the predominant crystalline phase of the Cr-N powder according to the GI-XRD investigation $[21,25,32]$. In addition, a weak reflection $43.6^{\circ}(2 \theta)$ was observed that may possibly be assigned to the $\mathrm{CrN}$ (200) orientation $[21,25]$. Both phases are according to the literature thermodynamically stable [21]. The main diffraction peaks of chromium metal were in addition observed. The calculated bulk compositional mass ratio of nitrogen to chromium (0.08), based on supplier information was lower than the stoichiometric ratio for $\mathrm{Cr}_{2} \mathrm{~N}$ (0.12) which support the occurrence also of chromium metal in the bulk powder. The presence of both $\mathrm{Cr}_{2} \mathrm{~N}$ and $\mathrm{CrN}$ was evident from analysis of the outermost surface by means of XPS. Cr, $\mathrm{N}, \mathrm{O}$, and $\mathrm{C}$ were the main elements observed on the surface. XPS spectra of Cr2 $\mathrm{p}_{3 / 2}$ and N1s are presented in Figure 2.

Three main components corresponding to different chemical chromium species were observed in the high-resolution $\mathrm{Cr} 2 \mathrm{p}_{3 / 2}$ spectrums. The first peak at $574.8 \pm 0.2 \mathrm{eV}$ was assigned to $\mathrm{Cr}_{2} \mathrm{~N}$ and the second component to $\mathrm{CrN}$, centred at $576.1 \pm 0.3 \mathrm{eV}$, in agreement with literature findings $[24,33]$. Due to peak overlap, this peak could also be attributed to $\mathrm{Cr}_{2} \mathrm{O}_{3}$ [34], also indicated by a distinct $\mathrm{O} 1 \mathrm{~s}$ peak at $530.6 \mathrm{eV}$ typical for $\mathrm{Cr}_{2} \mathrm{O}_{3}$ [24]. The presence of $\mathrm{CrN}$ was verified when resolving the $\mathrm{N} 1 \mathrm{~s}$ peak with nitrogen components assigned to nitride in $\mathrm{Cr}_{2} \mathrm{~N}$ and $\mathrm{CrN}$ observed at $398.1 \pm 0.3 \mathrm{eV}$ and $396.8 \pm 0.3 \mathrm{eV}$, respectively [24]. The proportion between the nitrogen peaks assigned to $\mathrm{Cr}_{2} \mathrm{~N}$ and CrN suggested a relative surface proportion of $1: 1$. A second component centred at $399.5 \pm 0.3 \mathrm{eV}$ was resolved from the N1s peak and was possibly attributed to chromium nitrates as reported in the literature [24]. A third component centred at $577.5 \pm 0.5 \mathrm{eV}$ was in addition resolved for the $\mathrm{Cr} 2 \mathrm{p}_{3 / 2}$ peak and assigned to other oxidised chromium(III) compounds such as $\mathrm{Cr}(\mathrm{OH})_{3}$ or $\mathrm{CrOOH}[24,33,34]$ with additional $\mathrm{O} 1 \mathrm{~s}$ peaks centred at $532.0 \pm 0.2$ and $533.4 \pm$ $0.2 \mathrm{eV}$. These oxygen peaks may also be attributed to $\mathrm{C}-\mathrm{O}$ 


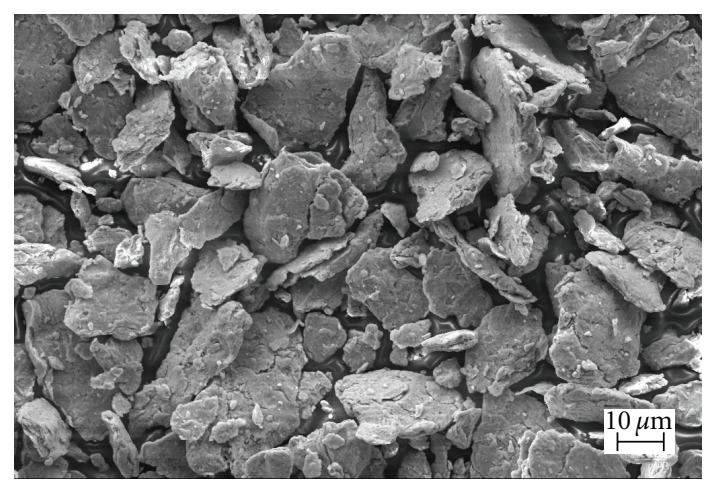

(a)

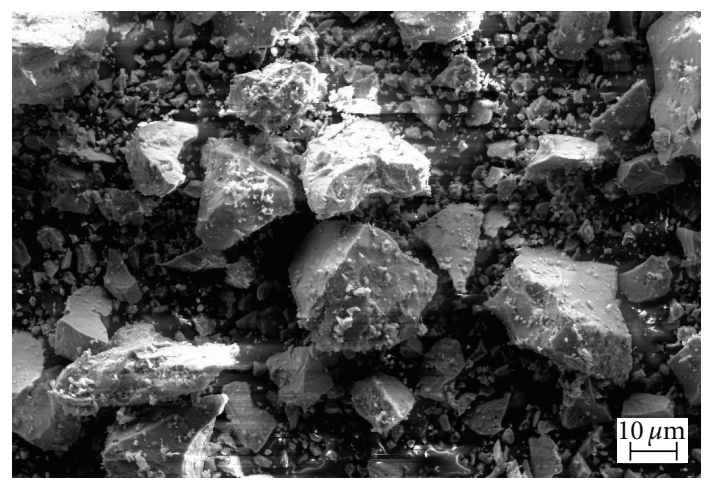

(c)

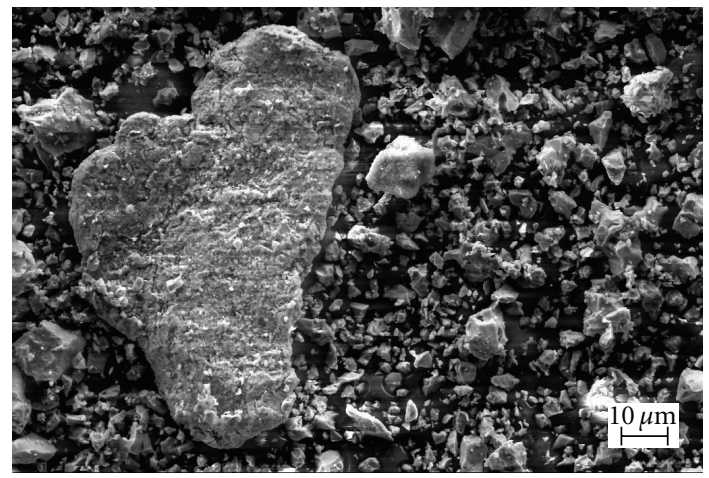

(e)

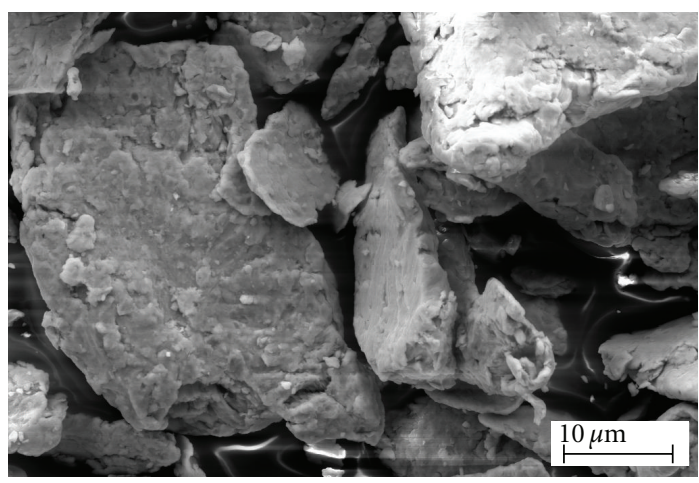

(b)

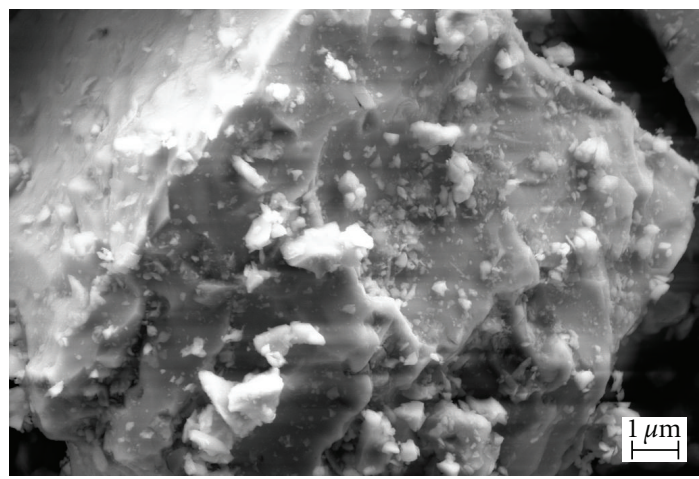

(d)

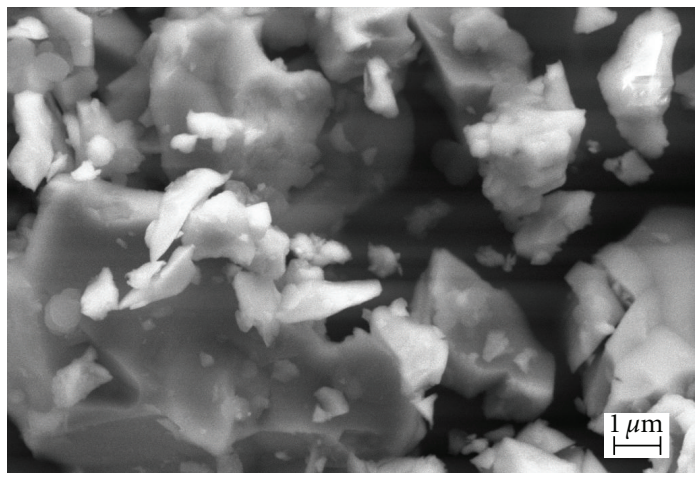

(f)

FiguRE 1: Secondary electron images of differences in shape and morphology of individual particles of Cr metal (a, b), Cr-N (c, d), and Cr-C $(e, f)$ powders by means of SEM.

and $\mathrm{C}=\mathrm{O}$ in oxidized carbon surface contaminants evident from the C1s spectra (spectra not shown) [24]. Similar observations with oxidised chromium on chromium nitride surfaces have been reported in the literature [22].

The identification of oxidized chromium compounds on the $\mathrm{Cr}-\mathrm{N}$ powder surface was consistent with findings for the Cr-metal powder that clearly revealed a metallic chromium peak at $574.4 \mathrm{eV}\left(\mathrm{Cr} 2 \mathrm{p}_{3 / 2}\right)$ and a peak at $576.0 \pm 0.2$ assigned to $\mathrm{Cr}_{2} \mathrm{O}_{3}(\mathrm{O} 1 \mathrm{~s} 530.4 \mathrm{eV})$ and a broad peak assigned to oxidized $\mathrm{Cr}(\mathrm{III})$ species such as $\mathrm{Cr}(\mathrm{OH})_{3}$ and $\mathrm{CrOOH}$, centred at $577.1 \pm 0.3 \mathrm{eV}[24,33,34]$.

$\mathrm{Cr}_{7} \mathrm{C}_{3}$ was the predominating crystalline phase determined with GI-XRD measurements of the $\mathrm{Cr}-\mathrm{C}$ powder showing all main reflections [23]. Its presence was furthermore supported by a calculated carbon to chromium bulk compositional mass ratio of 0.11 , very similar to its theoretical stoichiometric ratio $(0.10) . \mathrm{Cr}_{7} \mathrm{C}_{3}$ is according to literature findings the most thermodynamically stable existing chromium carbide compared with $\mathrm{Cr}_{3} \mathrm{C}_{2}$ and $\mathrm{Cr}_{23} \mathrm{C}_{6}$ [35]. The presence of chromium carbides was furthermore supported by XPS findings showing a C1s peak at $283.8 \mathrm{eV}$ corresponding to $\mathrm{Cr}-\mathrm{C}$ bonding and a $\mathrm{Cr} 2 \mathrm{p}_{3 / 2}$ peak at $574.6 \mathrm{eV}$ assigned to chromium carbide $\left(\mathrm{Cr}_{7} \mathrm{C}_{3}\right)[23,36]$. XPS also identified peaks attributed to oxidized chromium(III) species (in particular $\mathrm{Cr}_{2} \mathrm{O}_{3}$ ) similar to observations made for the Cr-N powder. 


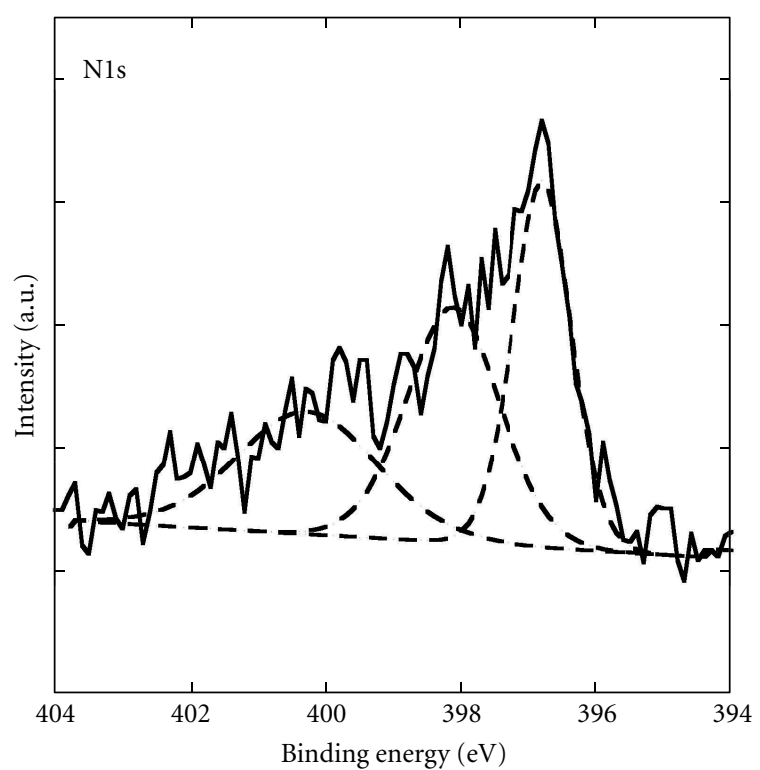

(a)

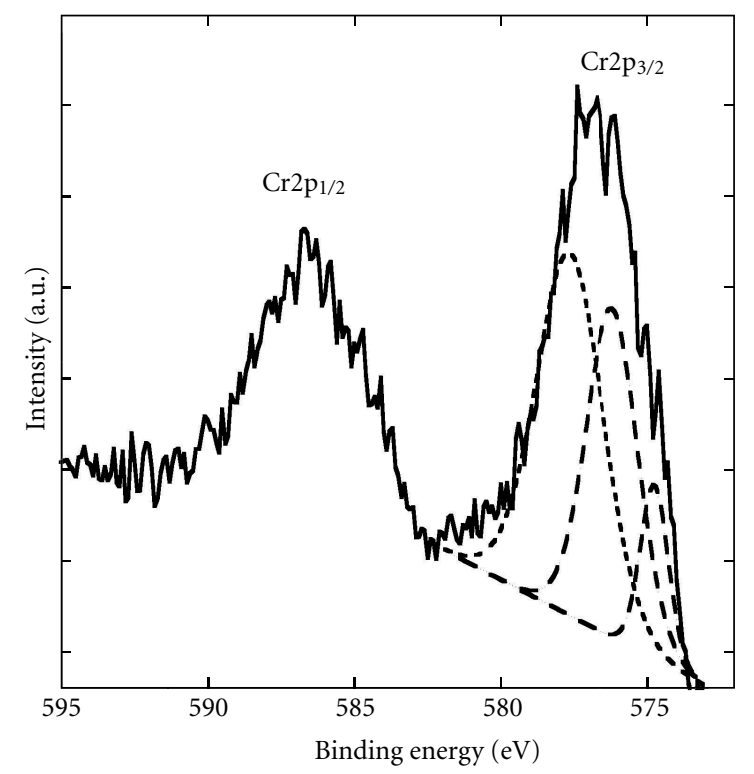

(b)

FIGURE 2: High resolution XPS spectra of N1s and Cr2 $\mathrm{p}_{3 / 2}$ for the Cr-N powder.

\subsection{Particle Size Distribution and Extent of Chromium Release} in Biological Solutions of Relevance for Human Exposure Scenarios. The size distribution of each powder in PBS is presented in Figure 3 and compiled in Table 4 both according to particle volume (mass) and particle number (only $\mathrm{Cr}-\mathrm{C}$ and $\mathrm{Cr}-\mathrm{N}$ ). Consistent with the morphological investigation with SEM, Figure 1, the Cr metal powder revealed a relatively even size distribution in solution with a mean particle size (based on volume) of $16 \mu \mathrm{m}\left(d_{0.5}\right)$, meaning that $50 \%$ of the particles had a diameter of $16 \mu \mathrm{m}$ or less. A noneven particle size distribution was observed for the Cr-N powder with two domains with $d_{0.5}$ values of 4 and
$26 \mu \mathrm{m}$ (volume). Differently sized particles were consistent with the morphological investigation by means of SEM, Figure 1. Smaller-sized particles $\left(d_{0.5}-1 \mu \mathrm{m}\right)$ present and partly shown by SEM to adhere to the larger particles of the Cr-N powder at dry conditions were dispersed in solution, Figure 3. Contradictory to the other powders, the Cr$\mathrm{C}$ powder was heterogeneous as illustrated by differences in number distribution between different samples. A large number distribution of both smaller $\left(d_{0.5}-0.3 \mu \mathrm{m}\right)$ and larger particles $\left(d_{0.5}-1.6 \mu \mathrm{m}\right)$ were observed for the $\mathrm{Cr}-\mathrm{C}$ powder. No sample heterogeneity was observed for the distribution of larger-sized particles by volume $\left(d_{0.5}-7.7 \mu \mathrm{m}\right)$.

The release of chromium from the different powders was quantified for time periods up to one week at standard conditions in artificial biological fluids of varying $\mathrm{pH}$ and composition of relevance for human contact. Since the release of dissolved metal species, an extent not possible to predict from bulk compositional data [2, 37], is believed to induce acute effects on human health, measurement of released metal species into artificial body fluids can indicate whether in vivo toxicity, at least acute is likely to occur.

The released amount of chromium of the total amount of chromium in the different powders was for all powders and test fluids very low $(<0.02 \%)$. This is illustrated in Figure 4 after 168 hours of exposure. The general trend for all powders was a slightly increased amount of released chromium with increasing fluid acidity, for example, artificial lysosomal fluid (ALF-pH 4.5) and gastric juice (GST-pH 1.5), see Figure 4. The released amount of chromium expressed as $\%(\mu \mathrm{g} \mathrm{Cr} / \mu \mathrm{g}$ $\left.\mathrm{Cr}^{*} 100\right)$ decreased according to the following sequences for the different powders:

(i) Cr-metal: GST $(<0.017 \%)>\operatorname{ALF}(<0.010 \%)>$ ASW $(<0.003 \%)>\operatorname{PBS}(<0.0002 \%) \approx \mathrm{GMB}(<0.0004 \%)$,

(ii) $\mathrm{Cr}-\mathrm{N}$ : GST $(<0.015 \%) \approx \operatorname{ALF}(<0.014 \%)>\operatorname{ASW}$ $(<0.007 \%)>\operatorname{PBS}(<0.0030 \%) \geqslant \operatorname{GMB}(<0.002 \%)$,

(iii) $\mathrm{Cr}-\mathrm{C}$ : GST $(<0.0050 \%) \geqslant \operatorname{ALF}(<0.0040 \%) \geqslant \mathrm{ASW}$ $(<0.003 \%)>\operatorname{PBS}(<0.0006 \%) \approx \mathrm{GMB}(<0.0008 \%)$.

Differences in release rates between the powders could not be attributed to differences in surface area (BET) at dry conditions, Figure 4(b), or to the corresponding particle size distribution in solution, (cf. Figure 3 ), since the lowest release was obtained from the powder with the largest surface area and smallest particle size $\left(\mathrm{Cr}-\mathrm{C}-1.26 \mathrm{~m}^{2} / \mathrm{g}\right)$, compared to $\mathrm{Cr}-\mathrm{N}\left(0.61 \mathrm{~m}^{2} / \mathrm{g}\right)$ with a significant number of smallersized particles and Cr-metal $\left(0.46 \mathrm{~m}^{2} / \mathrm{g}\right)$ with primarily larger-sized flake-like particles, (cf. Figure 2).

Very low concentrations of chromium were released from the chromium metal powder (specific surface area of $0.46 \mathrm{~m}^{2} / \mathrm{g}$ ) due to the presence of passive chromium(III)-rich surface oxides. After $168 \mathrm{~h}$ of in vitro exposures to synthetic biological fluids of different composition and $\mathrm{pH}$, the following released concentrations of chromium were determined; $<15 \mu \mathrm{g} / \mathrm{L}$ in artificial lysosomal fluid (ALF) and artificial gastric fluid (GST), $<3 \mu \mathrm{g} / \mathrm{L}$ in artificial sweat (ASW) and $<1.5 \mu \mathrm{g} / \mathrm{L}$ in PBS buffer and Gamble's solution (GMB). Even though a time and $\mathrm{pH}$ effect was evident, only less than $0.02 \%$ of the total amount of loaded powder was dissolved 


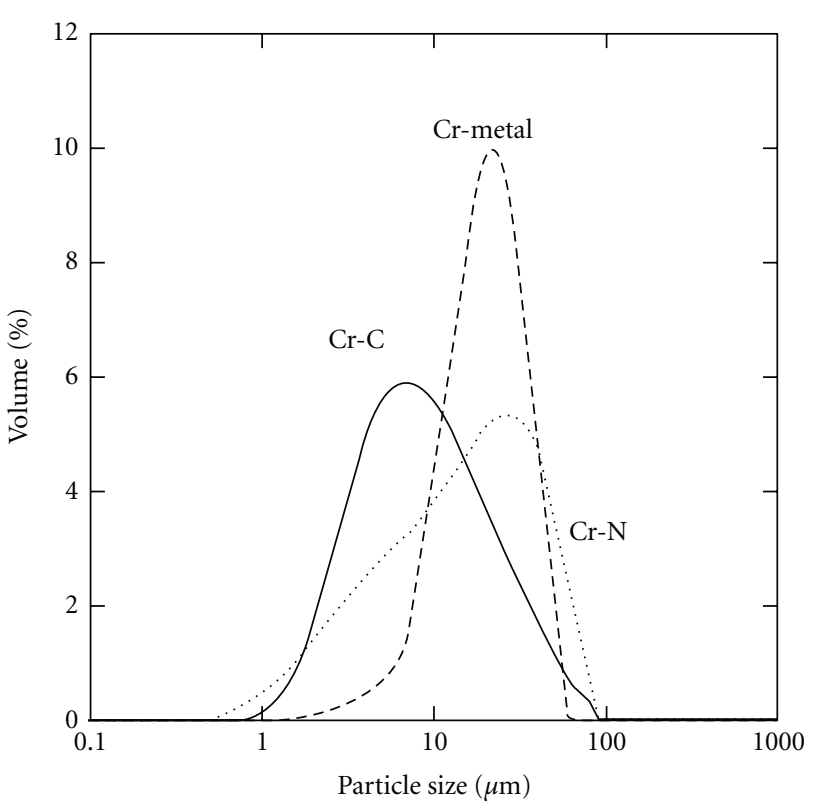

(a)

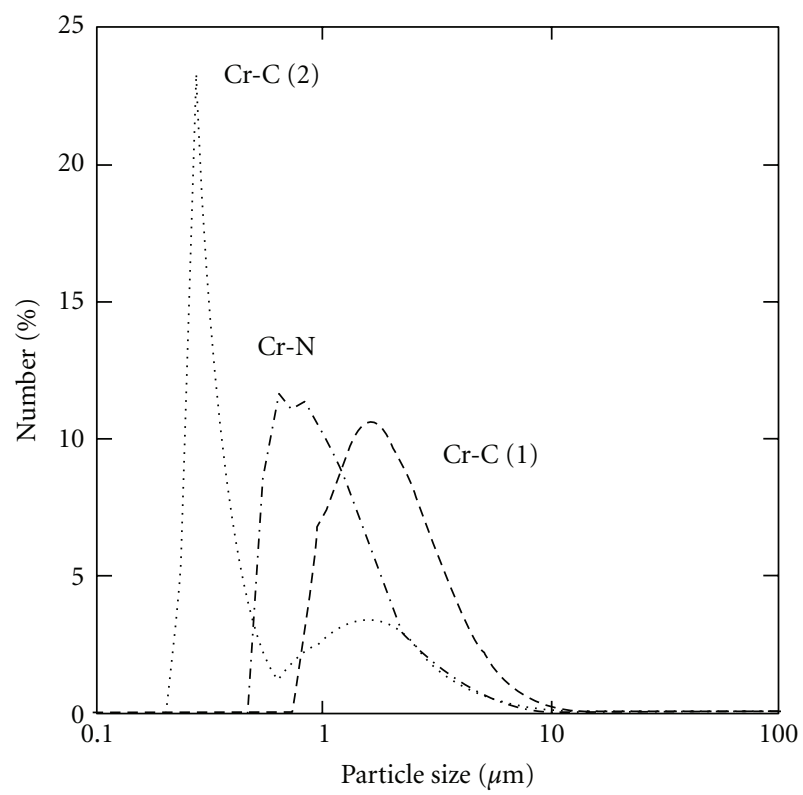

(b)

Figure 3: Particle size distributions by volume and numbers of the $\mathrm{Cr}$ metal, the $\mathrm{Cr}-\mathrm{C}$ (heterogeneous samples), and the $\mathrm{Cr}-\mathrm{N}$ powder in PBS determined by means of laser diffraction.

after 168 hours of exposure, see Figure 5. A higher amount of released chromium from surfaces of chromium-rich surface oxides exposed to solutions of high acidity is consistent with previous studies $[1,38]$.

The Cr-C powder was the least soluble powder investigated, probably due to strong covalent bonds within the matrix [39]. Chromium carbides are according to the literature chemically stable [40], insoluble in water and also nonsoluble or poorly soluble in $\mathrm{HCl}$ [12]. The release of chromium from $\mathrm{Cr}-\mathrm{C}$ occurred primarily during the initial
24 hours of exposure in the near-neutral solutions of GMB and PBS, Figure 5. Additional amounts of chromium, though still very low levels, were released between 24 and 168 hours to some extent in ASW and to a higher extent in the acidic media of ALF and GST. A slightly higher release of chromium after long exposure periods may be related to a partial dissolution of chromium(III) oxides observed on the surface of the Cr-C powder by means of XPS, an effect also observed for the $\mathrm{Cr}$-metal powder. The comparison with previously performed identical exposures of $\mathrm{Cr}_{2} \mathrm{O}_{3}$ powder in ASW and ALF $[1,38]$ shows higher released amounts of chromium from the $\mathrm{Cr}-\mathrm{C}$ powder, however, still at very low levels $\left(<0.005 \%\right.$ or $\left.0.00002 \mu \mathrm{g} / \mathrm{cm}^{2} / \mathrm{h}\right)$. This comparison was relevant since all powders revealed the presence of chromium(III) oxides, primarily $\mathrm{Cr}_{2} \mathrm{O}_{3}$ on the surface.

The release of chromium from the $\mathrm{Cr}-\mathrm{N}$ powder was after 168 hours approximately 2-3 times higher compared to $\mathrm{Cr}-\mathrm{C}$ powder in all fluids, though at still very low levels $(<0.015 \%$ of chromium released compared to the amount of chromium in the loaded powder). XPS analysis of $\mathrm{Cr}-\mathrm{N}$ particles exposed in GST for 168 hours shows that the $\mathrm{CrN} / \mathrm{Cr}_{2} \mathrm{~N}$ ratio in the outermost surface has increased from 1.3 to 2.4 compared with unexposed particles. These results are in agreement with literature where $\mathrm{Cr}_{2} \mathrm{~N}$ is significantly more soluble compared with $\mathrm{CrN}$ in $\mathrm{HCl}$ at $100^{\circ} \mathrm{C}$, and significantly more soluble in $\mathrm{HCl}$ compared with both $\mathrm{H}_{2} \mathrm{SO}_{4}$ and $\mathrm{HNO}_{3}$ [13]. Even though no information was provided for room temperature conditions, the results are in concordance with observations in this study with higher released amounts of chromium in GST (composed of $\mathrm{HCl}$, cf. Table 2) compared with the other fluids. Almost similar amounts of chromium were released in PBS ( $\mathrm{pH}$ 7.2) as in GST, at least during the first 24 hours, an observation that may be explained by similar molar concentrations of chloride, 0.15 and $0.17 \mathrm{M}$ in PBS and GST, respectively. Exposures in ALF and GST conveyed very similar amounts of released chromium after 168 hours of exposure $(0.014 \%$ dissolution, $0.00014 \mu \mathrm{g} / \mathrm{cm}^{2} / \mathrm{h}$ ). This effect could not be attributed to the molar concentration of chloride since it is significantly lower in ALF $(0.06 \mathrm{M})$ compared with GST. However, this may be explained by a higher dissolution of $\mathrm{Cr}_{2} \mathrm{~N}$ in this solution compared with $\mathrm{CrN}$ according to the findings of Lyutaya and Kulik [13] combined with a partial dissolution of chromium(III) oxides observed on the surface of the Cr-N powder by means of XPS. Another reason may be related to the presence of organic complexing agents such as citric acid in ALF, previously shown to enhance the release of metals including chromium from stainless steel [7, 41, 42].

Released amount of chromium is expressed as \% $(\mu \mathrm{g}$ $\mathrm{Cr} / \mu \mathrm{g} \mathrm{Cr} * 100)$.

\section{Conclusions}

Nonmetallic powders of chromium carbide (Cr-C) and chromium nitride $(\mathrm{Cr}-\mathrm{N})$ compared with chromium metal $(\mathrm{Cr}-$ metal) were characterised and exposed to in vitro environments simulating exposures in different human fluids and in surface waters. The aim was to generate unique solubility data to be used for the assessment of potential risks on 


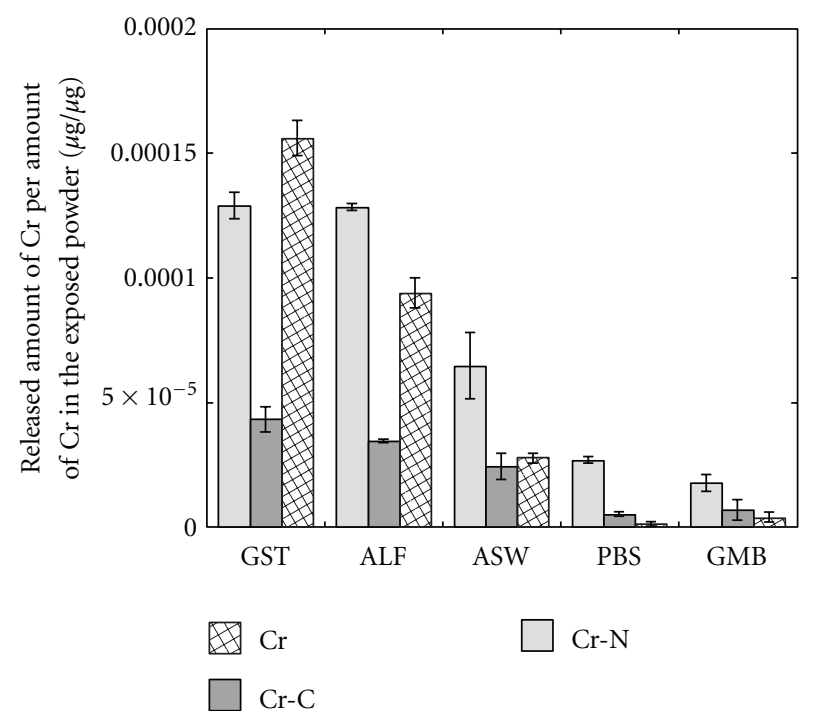

(a)

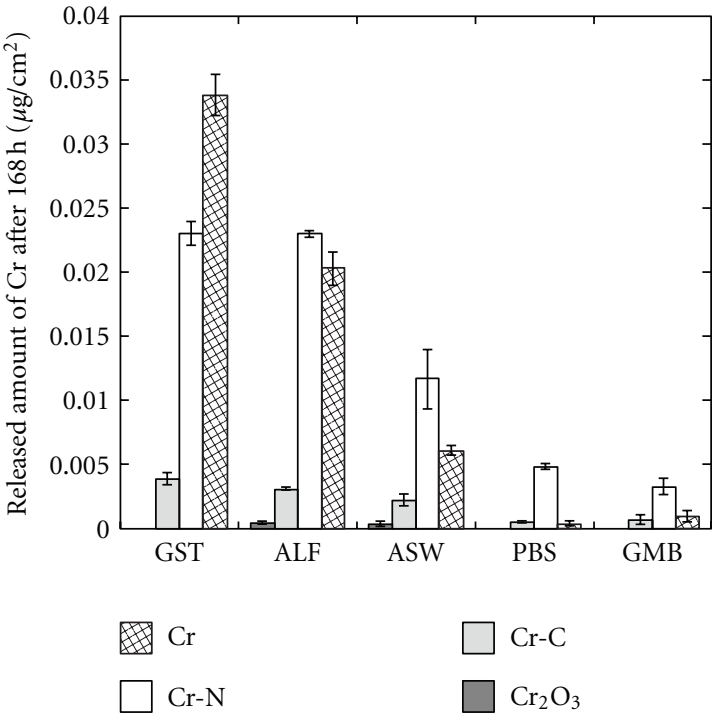

(b)

FIgURE 4: Release of chromium from powders of $\mathrm{Cr}-\mathrm{C}, \mathrm{Cr}-\mathrm{N}$ and $\mathrm{Cr}$-metal exposed for $168 \mathrm{~h}$ in different biological media expressed as the amount of chromium released per amount of chromium in the loaded powder $(\mu \mathrm{g} / \mu \mathrm{g})$, (a), and the released amount of chromium normalized to the surface area (BET). Reported literature data $[1,38]$ for $\mathrm{Cr}_{2} \mathrm{O}_{3}$ exposed at identical conditions is included for comparison. Error bars correspond to the standard deviation of triplicate samples.

TABLE 4: Measured median particle diameter $\left(d_{0.5}\right)$ and the $10 \%\left(d_{0.1}\right)$ and $90 \%\left(d_{0.9}\right)$ size distribution percentiles expressed as mass (volume) and numbers of the Cr metal-, the $\mathrm{Cr}-\mathrm{C}-$ (heterogeneous samples) and the $\mathrm{Cr}-\mathrm{N}$ powder in PBS using laser diffraction.

\begin{tabular}{lcccccc}
\hline Test item & $d_{0.1}$ volume & $d_{0.5}$ volume & $d_{0.9}$ volume & $d_{0.1}$ number & $d_{0.5}$ number & $d_{0.9}$ number \\
\hline Cr-metal & 7.3 & 16.1 & 30.1 & - & - & - \\
Cr-C (1) & 2.6 & 7.7 & 27.2 & 0.96 & 0.25 & 0.7 \\
Cr-C (2) & 2.6 & 7.9 & 26.7 & 0.52 & 0.35 & 2.8 \\
Cr-N & 2.6 & 14.5 & 43.9 & 0.87 & 2.0 \\
\hline
\end{tabular}

-not calculated.

human health and the environment induced by a potential exposure to these powders. The following main conclusions were drawn.

The released amount of chromium of the total amount of chromium expressed as \% ( $\left.\mu \mathrm{g} \mathrm{Cr} / \mu \mathrm{g} \mathrm{Cr}{ }^{*} 100\right)$ in the different powders was for all powders and test fluids very low $(<0.02 \%)$ or significantly lower depending on test fluid and $\mathrm{pH}$ ), and decreased according to the following sequences:

(i) Cr-metal: GST $(<0.017 \%)>\operatorname{ALF}(<0.010 \%)>$ ASW $(<0.003 \%)>\operatorname{PBS}(<0.0002 \%) \approx \operatorname{GMB}(<0.0004 \%)$,

(ii) $\mathrm{Cr}-\mathrm{N}$ : GST $(<0.015 \%) \approx \operatorname{ALF}(<0.014 \%)>\mathrm{ASW}$ $(<0.007 \%)>\operatorname{PBS}(<0.003 \%) \geqslant \operatorname{GMB}(<0.002 \%)$,

(iii) $\mathrm{Cr}-\mathrm{C}$ : $\operatorname{GST}(<0.005 \%) \geqslant \operatorname{ALF}(<0.004 \%) \geqslant \mathrm{ASW}$ $(<0.003 \%)>\operatorname{PBS}(<0.001 \%) \approx \operatorname{GMB}(<0.001 \%)$.

The particle size distributions of $\mathrm{Cr}-$ metal and $\mathrm{Cr}-\mathrm{N}$ were similar in addition resulting in comparable surface areas (BET). The Cr-metal particles were flake-like and fairly even in size whereas $\mathrm{Cr}-\mathrm{N}$ contained a large amount of smaller-sized particles both as individual particles and adhered to the surfaces of significantly larger boulder-like particles. Similar observations were made for $\mathrm{Cr}-\mathrm{C}$ except for a significantly larger amount of smaller-sized particles $(<10 \mu \mathrm{m})$ and only a small fraction of very large boulder-like particles $(40-50 \mu \mathrm{m})$ resulting in a surface area approximately twice that of $\mathrm{Cr}$ metal and $\mathrm{CrN}$.

$\mathrm{Cr}_{2} \mathrm{~N}$ was determined as the predominant constituent of the Cr-N powder supported by GI-XRD data and a calculated bulk compositional mass ratio of nitrogen to chromium of 0.09 , similar to its stoichiometric ratio (0.12). XPS findings suggested the additional presence of $\mathrm{CrN}$, also indicated by GI-XRD data and oxidised $\mathrm{Cr}$ (III)-oxides, in particular, $\mathrm{Cr}_{2} \mathrm{O}_{3}$ on the powder surface.

The main crystalline phase in the $\mathrm{Cr}-\mathrm{C}$ powder was, by GI-XRD, determined to be $\mathrm{Cr}_{7} \mathrm{C}_{3}$ confirmed by the similarity of the calculated compositional bulk mass ratio $(0.11)$ and the theoretical stoichiometric ratio (0.10). $\mathrm{Cr}_{7} \mathrm{C}_{3}$ was also the most abundant carbide observed using XPS in together with peaks attributed to $\mathrm{Cr}$ (III)-oxides, $\left(\mathrm{Cr}_{2} \mathrm{O}_{3}\right)$.

The $\mathrm{Cr}-\mathrm{C}$ powder was the by far least soluble powder investigated, probably due to strong covalent bonds within the matrix. Partial dissolution of the chromium(III) oxides observed on the surface of the $\mathrm{Cr}-\mathrm{C}$ powder may be associated with the slight increase in chromium release after long exposure periods. 


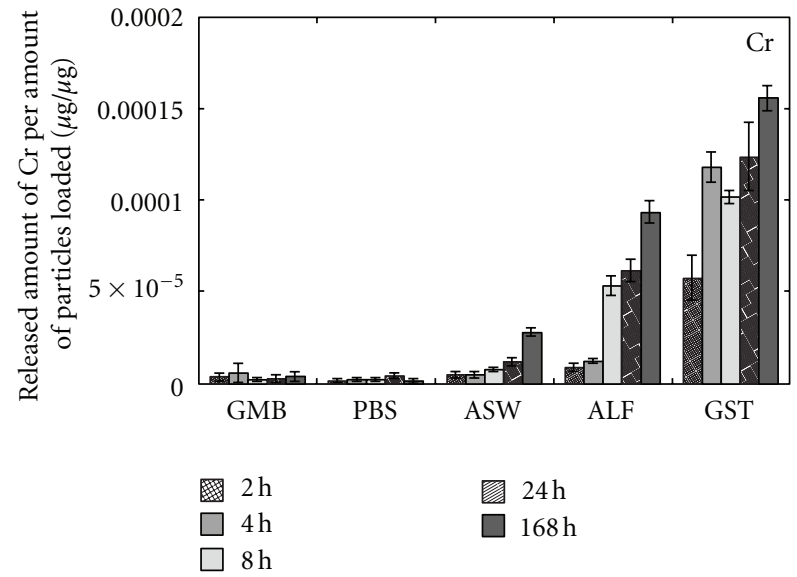

(a)

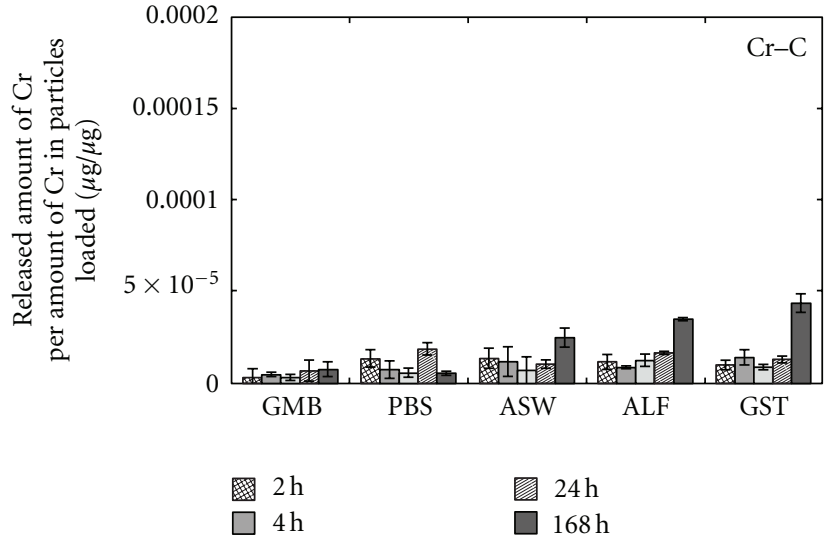

(b)

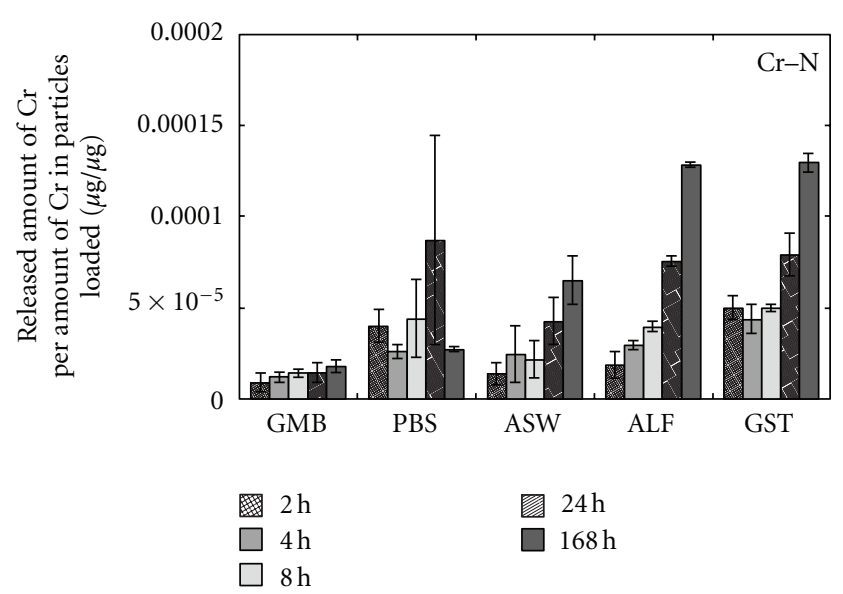

(c)

FIGURE 5: Release of chromium from powders of $\mathrm{Cr}-\mathrm{C}, \mathrm{Cr}-\mathrm{N}$ and $\mathrm{Cr}$-metal exposed up to $168 \mathrm{~h}$ in synthetic biological fluids of different $\mathrm{pH}$ and composition (GMB—Gamble's solution, $\mathrm{pH}$ 7.2; PBS—phosphate buffered saline, $\mathrm{pH}$ 7.4; ASW—artificial sweat, pH 6.5; ALFartificial lysosomal fluid, $\mathrm{pH}$ 4.5; GST-Gastric fluid, $\mathrm{pH}$ 1.7) expressed as the amount of chromium released per amount of chromium in the loaded powder ( $\mu \mathrm{g} \mathrm{Cr} / \mu \mathrm{g} \mathrm{Cr}$ in $\mathrm{Cr}-\mathrm{N}, \mathrm{Cr}-\mathrm{C}, \mathrm{Cr}$-metal). Error bars correspond to the standard deviation of triplicate samples. Relatively high standard deviations are related to powder heterogeneity and low released chromium concentrations $(<5 \mu \mathrm{g} / \mathrm{L})$.

A higher chromium release was observed from $\mathrm{Cr}-\mathrm{N}$ compared with $\mathrm{Cr}-\mathrm{C}$ and may be related to differences in solubility of $\mathrm{CrN}$ and $\mathrm{Cr}_{2} \mathrm{~N}$ where preferential dissolution of one together with partial dissolution of $\mathrm{Cr}_{2} \mathrm{O}_{3}$ at lower $\mathrm{pH}$ resulted in a by comparison increased chromium release.

\section{Acknowledgment}

The Chromium Metals Consortium is acknowledged for commissioning the study of bioaccessibility of chromium released from chromium carbide, chromium nitride, and chromium metal in synthetic biological media. Dr. Grant Darrie, ICDA, and Jean-Francois Chamaly, Delachaux, are highly appreciated for valuable discussions. The research reported in this article was jointly funded by Delachaux S.A. (Delachaux) and London \& Scandinavian Metallurgical Co. Ltd. (LSM). Delachaux and LSM retain data compensation rights under all regulatory and statutory programs, including, but not limited to REACH. Possession of a copy of this article, in whole or in part, does not constitute "legitimate possession" of the study and does not create any rights to use the study or the data presented herein for any chemical registration (such as, but not limited to, the REACH registration program) or any other commercial purpose.

\section{References}

[1] Y. Hedberg, K. Midander, and I. O. Wallinder, "Particles, sweat, and tears: a comparative study on bioaccessibility of ferrochromium alloy and stainless steel particles, the pure metals and their metal oxides, in simulated skin and eye contact," Integrated Environmental Assessment and Management, vol. 6, no. 3, pp. 456-468, 2010.

[2] K. Midander, A. D. Frutos, Y. Hedberg, G. Darrie, and I. O. Wallinder, "Bioaccessibility studies of ferro-chromium alloy particles for a simulated inhalation scenario: a comparative study with the pure metals and stainless steel," Integrated 
Environmental Assessment and Management, vol. 6, no. 3, pp. 441-455, 2010.

[3] M. Huvinen, A. Mäkitie, H. Järventaus et al., "Nasal cell micronuclei, cytology and clinical symptoms in stainless steel production workers exposed to chromium," Mutagenesis, vol. 17, no. 5, pp. 425-429, 2002.

[4] M. Huvinen, J. Uitti, P. Oksa, P. Palmroos, and P. Laippala, "Respiratory health effects of long-term exposure to different chromium species in stainless steel production," Occupational Medicine, vol. 52, no. 4, pp. 203-212, 2002.

[5] G. Hultquist, M. Seo, T. Leitner, C. Leygraf, and N. Sato, "The dissolution behaviour of iron, chromium, molybdenum and copper from pure metals and from ferritic stainless steels," Corrosion Science, vol. 27, no. 9, pp. 937-946, 1987.

[6] H. Y. Park and T. R. Shearer, "In vitro release of nickel and chromium from simulated orthodontic appliances," American Journal of Orthodontics, vol. 84, no. 2, pp. 156-159, 1983.

[7] Y. Hedberg, J. Hedberg, Y. Liu, and I. O. Wallinder, "Complexation- and ligand-induced metal release from 316L particles: importance of particle size and crystallographic structure," BioMetals, pp. 1099-1114, 2011.

[8] Y. Hedberg and I. O. Wallinder, "Transformation/dissolution studies on the release of iron and chromium from particles of alloys compared with their pure metals and selected metal oxides," Materials and Corrosion, vol. 62, no. 9999, 2011.

[9] V. Riihimäki and M. Luotamo, Health Risk Assessment Report for Metallic Chromium and Trivalent Chromium, International Chromium Development Association, 2006.

[10] A. Broadway, M. R. Cave, J. Wragg et al., "Determination of the bioaccessibility of chromium in Glasgow soil and the implications for human health risk assessment," Science of the Total Environment, vol. 409, no. 2, pp. 267-277, 2010.

[11] Z. X. Wang, J. Q. Chen, L. Y. Chai, Z. H. Yang, S. H. Huang, and Y. Zheng, "Environmental impact and site-specific human health risks of chromium in the vicinity of a ferro-alloy manufactory, China," Journal of Hazardous Materials, vol. 190, no. 1-3, pp. 980-985, 2011.

[12] V. N. Klimenko, "The strength of chromium carbide hard alloys," Soviet Powder Metallurgy and Metal Ceramics, vol. 3, no. 5, pp. 396-399, 1965.

[13] M. D. Lyutaya and O. P. Kulik, "Chemical properties of nitrides of some transition metals," Soviet Powder Metallurgy and Metal Ceramics, vol. 9, no. 10, pp. 821-826, 1970.

[14] C. K. Lee, "Electrochemical behaviour of chromium nitride coatings with various preferred orientations deposited on steel by unbalanced magnetron sputtering," Materials Science and Technology, vol. 22, no. 6, pp. 653-660, 2006.

[15] F. Cai, X. Huang, Q. Yang, R. Wei, and D. Nagy, "Microstructure and tribological properties of $\mathrm{CrN}$ and CrSiCN coatings," Surface and Coatings Technology, vol. 205, no. 1, pp. 182-188, 2010.

[16] P. Engel, G. Schwarz, and G. K. Wolf, "Corrosion and mechanical studies of chromium nitride films prepared by ion-beamassisted deposition," Surface and Coatings Technology, vol. 98, no. 1-3, pp. 1002-1007, 1998.

[17] Y. Ishikawa, S. Kuroda, J. Kawakita, Y. Sakamoto, and M. Takaya, "Sliding wear properties of HVOF sprayed WC$20 \% \mathrm{Cr}_{3} \mathrm{C}_{2}-7 \% \mathrm{Ni}$ cermet coatings," Surface and Coatings Technology, vol. 201, no. 8, pp. 4718-4727, 2007.

[18] R. F. A. Jargelius-Pettersson, "Electrochemical investigation of the influence of nitrogen alloying on pitting corrosion of austenitic stainless steels," Corrosion Science, vol. 41, no. 8, pp. 1639-1664, 1999.
[19] M. Taguchi and J. Kurihara, "Effect of surface nitriding on corrosion resistance of chromium in sulfuric acid solution," Materials Transactions, vol. 32, no. 12, pp. 1170-1176, 1991.

[20] O. S. Yurchenko, V. M. Knyazheva, Y. P. Kolosvetov, S. G. Babich, and V. B. Kozhevnikov, "Corrosion and electrochemical properties of hot-pressed chromium nitride," Soviet Powder Metallurgy and Metal Ceramics, vol. 26, no. 5, pp. 388-391, 1987.

[21] S. M. Aouadi, D. M. Mihut, M. L. Kuruppu, S. R. Kirkpatrick, and S. L. Rohde, "Spectroscopic ellipsometry measurements of chromium nitride coatings," Journal of Vacuum Science and Technology, Part A, vol. 19, no. 6, pp. 2800-2804, 2001.

[22] M. C. Biesinger, C. Brown, J. R. Mycroft, R. D. Davidson, and N. S. McIntyre, "X-ray photoelectron spectroscopy studies of chromium compounds," Surface and Interface Analysis, vol. 36, no. 12, pp. 1550-1563, 2004.

[23] M. Detroye, F. Reniers, C. Buess-Herman, and J. Vereecken, "AES-XPS study of chromium carbides and chromium iron carbides," Applied Surface Science, vol. 144-145, no. 1-4, pp. 78-82, 1999.

[24] A. Lippitz and T. Hübert, "XPS investigations of chromium nitride thin films," Surface and Coatings Technology, vol. 200, no. 1-4, pp. 250-253, 2005.

[25] Z. Han, J. Tian, Q. Lai, X. Yu, and G. Li, "Effect of $\mathrm{N}_{2}$ partial pressure on the microstructure and mechanical properties of magnetron sputtered $\mathrm{CrN}_{x}$ films," Surface and Coatings Technology, vol. 162, no. 2-3, pp. 189-193, 2003.

[26] S. C. Hamel, B. Buckley, and P. J. Lioy, "Bioaccessibility of metals in soils for different liquid to solid ratios in synthetic gastric fluid," Environmental Science and Technology, vol. 32, no. 3, pp. 358-362, 1998.

[27] ASTM, "Standard test method for determining extractability of metals from art materials," Annual Book of ASTM Standards, 2003.

[28] W. Stopford, J. Turner, D. Cappellini, and T. Brock, "Bioaccessibility testing of cobalt compounds," Journal of Environmental Monitoring, vol. 5, no. 4, pp. 675-680, 2003.

[29] "Reference test method for release of nickel from products intended to come into direct and prolonged contact with the skin," European Standard, EN1811, 1998.

[30] A. De Meringo, C. Morscheidt, S. Thelohan, and H. Tiesler, "In vitro assessment of biodurability: acellular systems," Environmental Health Perspectives, vol. 102, no. 5, pp. 47-53, 1994.

[31] A. Norlin, J. Pan, and C. Leygraf, "Investigation of interfacial capacitance of Pt, Ti and TiN coated electrodes by electrochemical impedance spectroscopy," Biomolecular Engineering, vol. 19, no. 2-6, pp. 67-71, 2002.

[32] A. Sankaran, P. K. Ajilumar, M. Kamruddin et al., "Gas phase nitridation of chromium plated stainless steel," in Proceedings of the International Symposium of Research Students on Material Science and Engineering, 2004.

[33] J. Lin, B. Mishra, J. J. Moore, and W. D. Sproul, "A study of the oxidation behavior of $\mathrm{CrN}$ and CrAlN thin films in air using DSC and TGA analyses," Surface and Coatings Technology, vol. 202, no. 14, pp. 3272-3283, 2008.

[34] P. Stefanov, D. Stoychev, M. Stoycheva, and T. Marinova, "XPS and SEM studies of chromium oxide films chemically formed on stainless steel 316 L," Materials Chemistry and Physics, vol. 65, no. 2, pp. 212-215, 2000.

[35] M. Čekada, P. Panjan, M. Maček, and P. Šmíd, "Comparison of structural and chemical properties of Cr-based hard coatings," Surface and Coatings Technology, vol. 151-152, pp. 31-35, 2002. 
[36] F. Maury, D. Oquab, J. C. Manse, R. Morancho, J. F. Nowak, and J. P. Gauthier, "Structural characterization of chromium carbide coatings deposited at low temperature by low pressure chemical vapour decomposition using dicumene chromium," Surface and Coatings Technology, vol. 41, no. 1, pp. 51-61, 1990.

[37] G. Herting, I. Odnevall Wallinder, and C. Leygraf, "A comparison of release rates of $\mathrm{Cr}, \mathrm{Ni}$, and $\mathrm{Fe}$ from stainless steel alloys and the pure metals exposed to simulated rain events," Journal of the Electrochemical Society, vol. 152, no. 1, pp. B23B29, 2005.

[38] Y. Hedberg, J. Gustafsson, H. L. Karlsson, L. Möller, and I. O. Wallinder, "Bioaccessibility, bioavailability and toxicity of commercially relevant iron- and chromium-based particles: in vitro studies with an inhalation perspective," Particle and Fibre Toxicology, vol. 7, article no. 23, 2010.

[39] D. Music, U. Kreissig, R. Mertens, and J. M. Schneider, "Electronic structure and mechanical properties of $\mathrm{Cr}_{7} \mathrm{C}_{3}$," Physics Letters, Section A, vol. 326, no. 5-6, pp. 473-476, 2004.

[40] K. E. Burke, "Chemical extraction of refractory inclusions from iron- and nickel-base alloys," Metallography, vol. 8, no. 6, pp. 473-488, 1975.

[41] R. F. Carbonaro, B. N. Gray, C. F. Whitehead, and A. T. Stone, "Carboxylate-containing chelating agent interactions with amorphous chromium hydroxide: adsorption and dissolution," Geochimica et Cosmochimica Acta, vol. 72, no. 13, pp. 3241-3257, 2008.

[42] Y. Zhang, N. Kallay, and E. Matijević, "Interactions of metal hydrous oxides with chelating agents. 7. Hematite-oxalic acid and -citric acid systems," Langmuir, vol. 1, no. 2, pp. 201-206, 1985. 

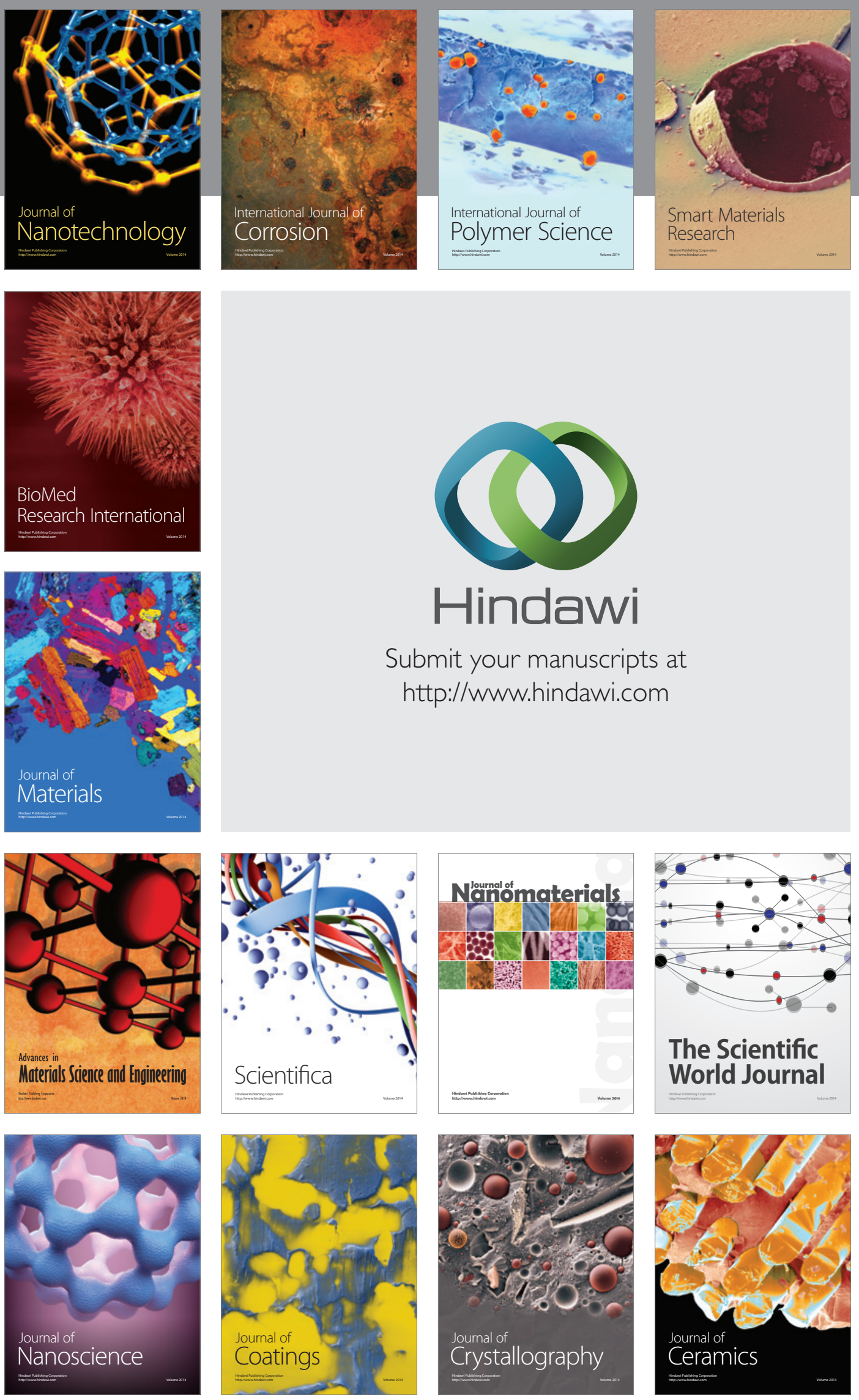

The Scientific World Journal

Submit your manuscripts at

http://www.hindawi.com

\section{World Journal}

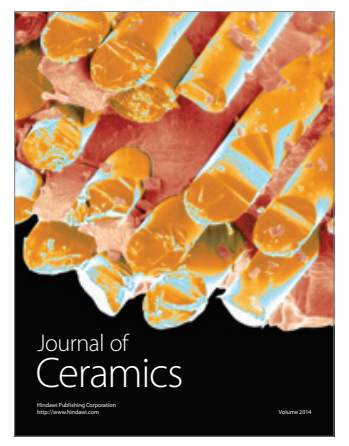

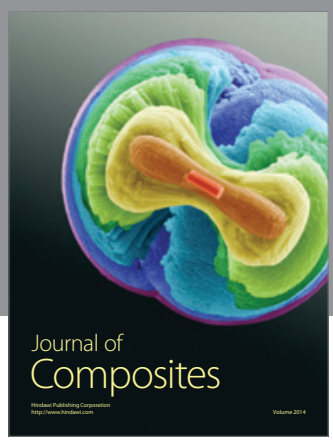
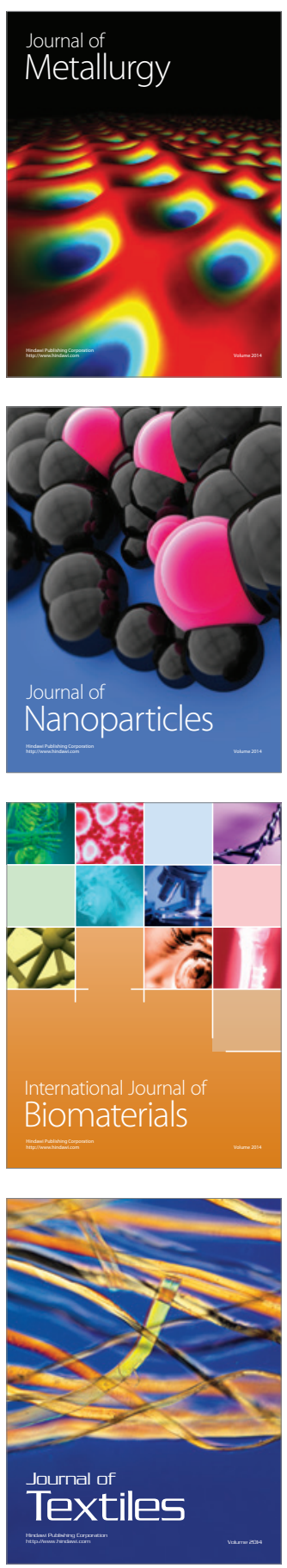